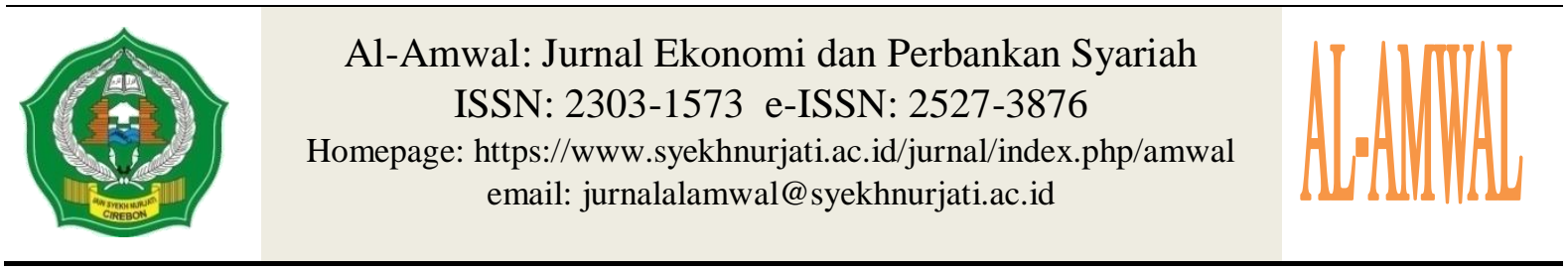

\title{
The Effect of Unemployment, Economic Growth on Poverty with Zakat as a Moderation Variable
}

\author{
Musalim Ridlo \\ Pascasarjana IAIN Salatiga \\ E-mail: syahr9233@gmail.com \\ Fitalia Indah Sari \\ Alumni Fakultas Ekonomi dan Bisnis Islam IAIN Salatiga \\ E-mail: Indahsarifitalia@gmail.com
}

\begin{abstract}
This study aims to analyze the effect of unemployment and economic growth (PDRB) on poverty in Java in 2012-2017 using the zakat variable as a moderating variable. This study uses secondary data types with the panel data model, namely annual data from the variable unemployment, economic growth (PDRB), zakat and poverty from six provinces in Java. Furthermore, the data were tested using multiple linear regression models and moderated regression analysis (MRA) with the help of SPSS version 16. The results showed that unemployment had a significant positive effect, economic growth (PDRB) had no significant positive effect, while the only zakat was able to moderate the unemployment variable towards poverty, and was unable to moderate economic growth variable (PDRB) to poverty.
\end{abstract}

Keywords: Poverty, Unemployment, Economic Growth (PDRB), and Zakat.

\begin{abstract}
Abstrak
Penelitian ini bertujuan untuk menganalisis pengaruh pengganguran dan pertumbuhan ekonomi (PDRB) terhadap kemiskinan di pulan Jawa periode 2012-2017 dengan menggunakan variabel zakat sebagai variabel moderasi. Penelitian ini menggunakan jenis data sekunder dengan model data panel, yaitu data tahunan dari variabel penggangguran, pertumbuhan ekonomi (PDRB), zakat dan kemiskinan dari enam provinsi di pulau Jawa. Selanjutnya, data di uji menggunakan model regresi linear bergandasertaujimoderated regression analysis (MRA) dengan bantuan aplikasi SPSS versi 16. Hasil penelitian menunjukkan bahwa pengangguran berpengaruh positif signifikan, pertumbuhan ekonomi (PDRB) berpengaruh positif tidak signifikan, sedangkan hanya zakat mampu memoderasi variabel pengangguran terhadap kemiskinan, dan tidak mempu memoderasi variabel pertumbuhan ekonomi (PDRB) terhadap kemiskinan.
\end{abstract}

Kata kunci: Kemiskinan, Pengangguran, Pertumbuhan Ekonomi(PDRB), Zakat 


\section{INTRODUCTION}

National development is an effort the wording improve and improve the quality of life of the community, reduce unemployment \& poverty, and increase the level of community income. In the 1945 Constitution, it is stated that the phrase to realize public welfare. In general, the problem faced by many countries related to community welfare is the inability of people to meet their needs, caused by poverty(Masruroh, Yulia, Supono, 2014). Poverty is a multidimensional problem, which consists of primary and secondary aspects. Poverty in the primary aspects the verb form; poor assets, social political organization, knowledge and skills. While the secondary aspects include; poor social networks, capital and, information(Arsyad L, 2015).

The Central Statistics Agency (BPS) revealed that poverty is the inability to meet basic needs such as food and non-food measured from the expenditure side. In Indonesia, the number of poverty up to 2017 was 27.77 million people and, the largest amount of poverty was in Java, amounting to 14.79 million people (BPS, 2019). Poverty is caused by several factors such as unemployment and economic growth. An area is often faced with a large number of unemployed and, labor force growth that is not proportional to the relatively small number of jobs. This makes the problem of poverty more serious(Masruroh, Yulia, Supono, 2014).

The unemployment rate in Indonesia in 2017 which is divided by provinces are Java at 5.8\%, Maluku and Papua at 5.4\%, Sumatra at 5.2\%, Kalimantan at 5\%, Sulawesi $4.9 \%$ and Bali and Nusa Southeast of $2.7 \%$. Another factor affecting poverty is economic growth, where the higher the income, the higher the level of community welfare. In this case, economic growth is illustrated through Gross Regional Domestic Revenue (GDP). Economic growth in Indonesia based on islands in 2017, namely: Sulawesi islands by $6.49 \%$, Java by $5.41 \%$, Maluku and Papua by $4.52 \%$, Sumatra by $4.09 \%$ and Bali and Nusa Tenggara by 3, $41 \%$ (www.katadata.com).

While GDP growth in Java based on constant 2010 prices, in the 2012-2017 period was dominated by DKI Jakarta Province with an average GDP of 6.09\%, Banten Province with an average GDP of 5.91\%, Java Province West average GDP of 5.56\%, Central Java Province the average GDP of 5.29\% and the Province of DIY the average GDP of 5.21\% (BPS, 2019). In addition to unemployment and economic growth, there is zakat which can indirectly affect poverty. As is known that the potential for zakat in Indonesia is very large. In 2015, based on research conducted by the National Amil Zakat Agency (BAZNAS), the potential for zakat in Indonesia reached Rp 286 trillion(BAZNAS, 2018).

In overcoming the problem of poverty, Islam has one pillar out of five pillars that are both vertically and horizontally oriented, namely the obligation of a Muslim to pay zakat. Zakat has a simple concept that is in the wealth of the rich there are rights of the poor that must be fulfilled. Zakat is more emphasized in terms of income distribution efforts (Muthohar, 2016). This is relevant to the word of God in the QS. Al Hasyr (59: 7) which means: "... that treasure should not be circulated among rich people only among you, ...". If zakat is managed professionally by people who are experts in the field and applies good principles and takes an example from the practice of the Prophet, the zakat will really be a solution to the various problems of the people(Sularno, 2010).

This study is relevant to research conducted by (Amalia, 2017), which says that unemployment has a significant positive effect on poverty as well as research conducted by (Amins, 2017), which says that unemployment rate is not significantly positive effect on poverty. The wording, research conducted by (Romi \& Umiyati, 2018), said that economic growth had a significant negative effect and research conducted by (Susanti, 2013), which said that economic growth was not significantly positive effect. While research conducted by 
(Purnomo, 2018), says that zakat the wording moderate the variable unemployment and economic growth.

From the description above, there are a number of problem formulations namely; (1) How is the effect of unemployment on poverty in Java in 2012-2017, (2) How is the effect of economic growth (GDP) on poverty in Java in 2012-2017, (3) Is zakat able to moderate the effect of unemployment on poverty in Java 2012-2017, (4) Is zakat able to moderate the effect of economic growth (GDP) on poverty in Java in 2012-2017.

\section{LITERATURE REVIEW \\ Previous Research}

Previous research on the effect of unemployment on poverty was carried out by (Anak Agung Istri Diah Paramita, 2015), entitled "The Effect of Investment and Unemployment on Economic Growth and Poverty in the Province of Bali" using a sociative quantitative approach and methods of collecting non-participant observation data and using analytical techniques path (path analysis). The results showed that the unemployment variable directly had a positive and significant effect on poverty in the province of Bali, and indirectly unemployment had a significant effect on poverty in the province of Bali through economic growth.

Previous research on the effect of economic growth on poverty was conducted by (Romi \& Umiyati, 2018), with the title "The Effect of Economic Growth and Minimum Wages on Poverty in Jambi City". By using multiple linear regression analysis tools in the form of semilog. The results of his research indicate that partially economic growth has no significant effect on poverty.

Research on the influence of zakat on poverty as a moderating variable has previously been carried out by(Purnomo, 2018), with the title "The Effect of Zakat Management on Poverty Alleviation with Zakat Empowerment and Zakat Utilization as Moderation Variables". The results of his research indicate that the management of zakat through the utilization of zakat has a positive effect of 12,791 on poverty reduction.

\section{Theory Framework}

The theoretical framework that will be developed in this study refers to the review of various literature that has been done. Based on the literature review above, the theoretical framework that will be developed in this study is as follows:

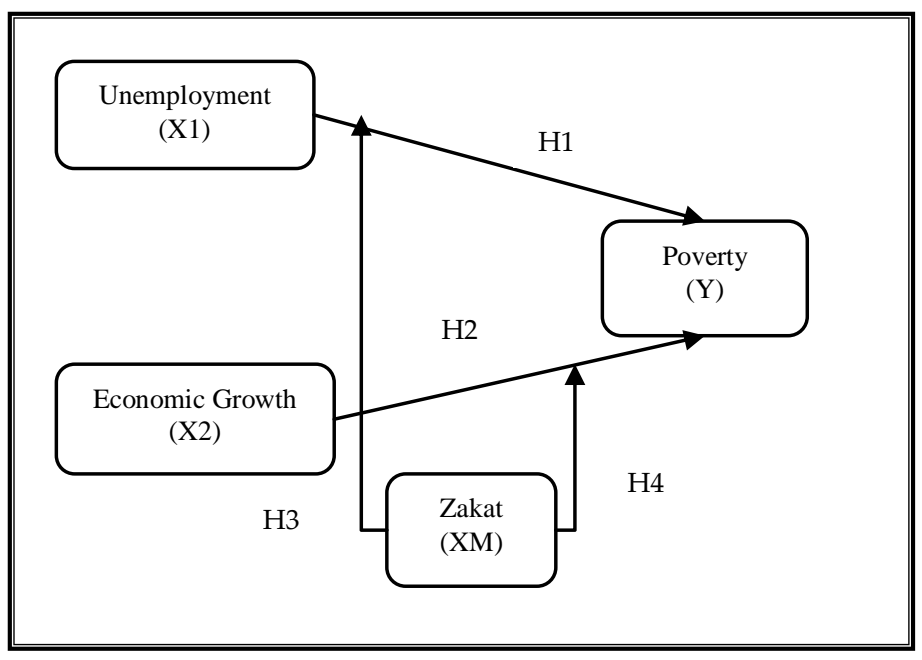

Figure 1. Theory Framework Poverty 
Poverty can be broadly illustrated by lack of or lack of education, poor health conditions, and lack of transportation needed by the community. The problem of poverty becomes an inspiration for change (the case of poverty) in an order of life. As it is known, life an article which is the desire of the people is a prosperous condition. Thus, this condition indicates the existence of a low standard of living, which in this case is the main target of efforts to improve the quality of life the wording create a prosperous society. Poverty conditions from various dimensions and their implications is one form of social problems that describes the conditions of low welfare. Therefore, it is natural that poverty can be an inspiration for change actions to improve people's welfare (Soetomo., 2008).

\section{Theory of poverty}

The theory of the vicious cycle of poverty was first introduced by Ragnar Nurkse. Poverty circle is defined as a set of forces that influence each other so that it can lead to a condition in which a State will remain poor and will experience difficulties in achieving higher levels of development. According to Nurkse, poverty is not only caused by the absence of development in the past, but poverty can also hamper development in the future. According to Nurkse, one of the factors that caused a cycle of poverty was the existence of obstacles in the process of forming a very strong capital (Arsyad L, 2015).

In this case, there are two types of poverty circles, namely; (1) in terms of capital supply, if the level of productivity is low, it will result in a low level of income. This will have an impact on people's ability to save. If the amount of savings is small, capital an article formation will be disrupted, as a result, a State will lack capital goods, (2) in terms of capital demand, where the factors that make investment low, due to the limited market area for various types of goods. That is, due to low community income and low productivity, which is caused by low capital formation due to limited investment drivers.

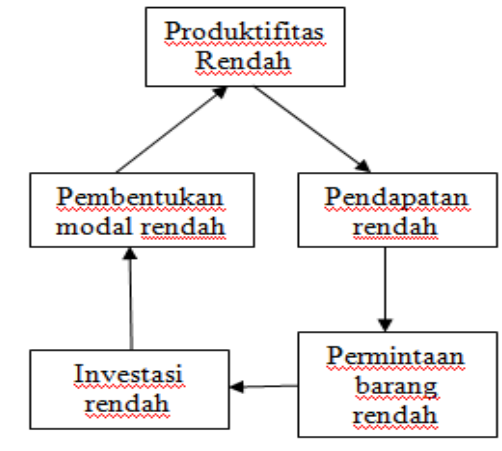

DEMAND

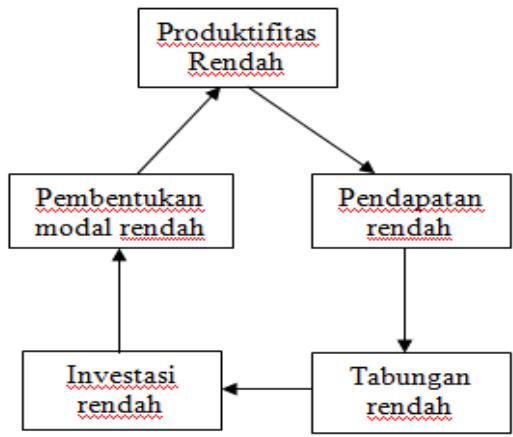

SUPPLY

Source:(Kuncoro, 2010)

Figure 2. Nurkse's Version Cycle of Poverty

\section{Indicator of poverty}

According to the Central Statistics Agency (BPS), revealed that to measure the poverty line using the poor limit of the components of the basic needs of the community, namely food and non-food needs, which are arranged based on urban and rural areas in accordance with the results of the National Socio-Economic Survey (SUSENAS). The purpose of the regional differentiation is a different cost of living. In this case, BPS uses the basic needs approach 
and headcount index approach. The approach that is often used in measuring poverty is the basic needs approach(Alie, 2015). BPS states that the concept of poverty is the inability to meet basic needs. The number of poor people is the number of people below the poverty line, which is divided into two kinds, namely the food and non-food poverty lines.

\section{Unemployment}

The Central Statistics Agency (BPS) states that unemployment is a workforce that is not yet working and is looking for a job or is preparing or population that already has a job but has not started it (www.bps.go.id). While Sukrino, adding that unemployment is a condition in which someone who is included in the labor force who wants to get a job but has not got it (Sukirno, 2006).

\section{The factors of unemployment}

There are several factors that cause unemployment including: (1) wanting to find a better job, (2) human power is replaced with mechanical power, (3) a mismatch between the expertise of workers and those needed in the company (Sukirno, 2006).

\section{Economic growth}

Economic growth is an increase in gross national product in a country(Beik, Irfan Syauqi \& Arsyanti, 2016).

\section{The factors of economic growth}

Base on(Arsyad L, 2015), expressed that the wording the economic growth of a society (state), namely:

1. Capital accumulation

Capital accumulation can be interpreted as the activity of storing income results in the present which are then invested, with the hope of making a profit, so that it can enlarge output in the future.

2. Population growth

An increase in the number of the workforce has traditionally affected economic growth.

3. Technological advances

Technology is a means of achieving production efficiency and effectiveness.

4. Institutional resources in this case, there are four functions of the institution, including (1) creating markets, (2) regulating markets, (3) maintaining stability, and (4) legitimizing markets.

\section{Zakat}

Base on(Muthohar, 2016), it states that zakat is etymologically derived from the word zaka $y a z k u$, which means growth (name '), purity (thaharah), blessing (barakah), and virtue (ash salahu). As for zakat in terms of shar'i, although the scholars express it with a slightly different editorial from one another in principle the same, namely that zakat is a portion of the property with certain conditions, which Allah requires to its owner, to be handed over to who is entitled to receive it, with certain conditions as well.

\section{Indicator of Zakat}

Base on(ADESY, 2016), there are several indicators or criteria for zakat giving (muzakki), namely: (1) Muslim, (2) independent, (3) fully owned, (4) achieving nishab, (5) ) reach haul.

\section{METHODE}

\section{Type of research}

This type of research is quantitative research, quantitative research is research conducted by collecting data in the form of data numbers, then processed and analyzed to obtain behind these numbers (Martono, 2011).

\section{Sample}


According to (Bawono, 2006), samples are objects or subjects taken from the population to represent the whole population. Based on the nature of the data, then in determining the number of samples to be used, this study uses a saturated sample technique or also often referred to as census samples. Census saturation sampling is a sampling technique if all members of the population are used as a sample. The sample used in this study was unemployment, economic growth (GDP), zakat and poverty in Java in 2012-2017

\section{Analysis technique}

This study uses multiple linear regression analysis and moderated regression analysis (MRA). According to (Bawono, Anton \& Sina, 2018), the linear regression model in panel data on the observation of the $\mathrm{i}$-th and t-time individuals with $\mathrm{K}$ independent variables is presented as follows:

Information:

$$
Y_{\mathrm{it}}=\beta_{0}+\beta_{1} \mathrm{X}_{\mathrm{iit}}+\beta_{2} \mathrm{X}_{\mathrm{it}} \text { it } \varepsilon_{\mathrm{it}}
$$

Yit: Poverty Variable

$\alpha$ : Interception

$\mathrm{X} 1$ : Unemployment

X2: Economic Growth

$\varepsilon$ : Error term

i: cross section data

t: time period data

Moderate Regression Analysis (MRA) is a special application of multiple linear regression, in which the regression equation contains elements of interaction, namely multiplication between two or more independent variables (Ghazali, 2011).

\section{RESULT AND DISCUSSION Stationarity test}

According to (Rizal \& Akbar, 2015), stationary testing is a condition if the generation process that underlies a periodic series is based on a constant mean value and a constant variance value. An observation data is said to be stationary if the process does not change with the changing time. In this study, the stationarity test used was the Root Unit test with the Augmented-Dickey-Fuller (ADF) test.

Based on the processed data shows output with a probability value smaller than 0.05 . Thus the stationarity test for each variable in this study meets the requirements of the stationarity test and is feasible to proceed with further data testing.

\section{Normality test}

According to Ghozali in (Sullutenggomalut \& Sadjab, 2016), said that the normality test is carried out to find out whether in the regression model the confounding or residual variables have a normal distribution. It is known that the probability value of 0.683883 shows that the value is greater than 0.05 , so the data is normally distributed.

\section{Multicolinearity test}

According to (Bawono, Anton \& Sina, 2018), multicollinearity is a situation in which there is a perfect or definite linear relationship between some or all of the independent variables of the multiple regression model. In broad terms, it means that there is a high correlation between independent variables. This study will use auxiliary regression to detect the presence of multicollinearity. The criterion is if the auxiliary regression R2 is greater than the overall regression $\mathrm{R} 2$, then in the model multicolinierality occurs between the independent variables and vice versa. Based on the processed data, the value of $\mathrm{r} 2$ auxiliary regression there are four variables that exceed the value of $\mathrm{R} 2$ in the main regression, so it can be concluded that the 
regression model in this study experiences multicollinearity. So the need for treatment of the regression test by reducing one or more variables that exceed the main R2.

Based on the proceesed data, the comparison of $\mathrm{R} 2$ after treatment, it can be seen that there is no relationship between the independent variable and the value of R2 in the main regression value. So it can be concluded that the variable data in this study do not have multicollinearity. The variables that are eliminated are the unemployment and unemployment variables in moderation with zakat.

\section{Autocorrelation test}

Testing autocorrelation in a model aims to determine whether there is a correlation between confounding variables at a certain period with the previous variable. For time series data autocorrelation often occurs. But for the sample data cross section rarely occurs because the confounding variables differ from one another(Sujarweni, 2015). In detecting the presence or absence of autocorrelation can be done with the Durbin-Watson test (DW test) with the criteria du < dw <4-du (Bawono, 2006).

Based on the proceesed data, shows the number 2.520735 which is not between the du and 4du values which indicate the numbers 1.7245 and 2.2755. Then, it can be concluded that the data contain autocorrelation. The Durbin-Watson value shows the number 1.967669 which is between the value of du and 4-du which shows the numbers 1.7245 and 2.2755. Then, it can be concluded that the data does not contain autocorrelation.

\section{Heteroscedasticity test}

According to Prasetya in (Romdhoni \& Ratnasari, 2018), said that heteroscedasticity is a residual variable variance that is not the same in all observations in the regression model. Based on the proceesed data, the regression test results are not affected by heteroscedasticity because the probability value is greater than 0.05 .

\section{RESULT AND DISCUSSION \\ Effect of Economic Growth (GDP) on Poverty}

From the test results obtained a positive coefficient of 16.14497 with a probability value of 0.1183 greater than $0.05(\alpha)$, in other words, Economic Growth (GDP) has a positive and not significant effect on poverty so $\mathrm{H} 2$ is rejected. According to (Sukirno, 2006), the rate of economic growth is an increase in GDP regardless of whether the increase is greater or smaller.

Gross Regional Domestic Product (GDP) as a whole, but must discuss where the distribution of income has spread the layers of society and also who has enjoyed the results. Reducing GDP as one of the priorities for improving household quality. And the amount of money spent is very limited, many poor households change their basic food patterns to the cheapest goods with a reduced amount of goods(Giovanni, 2018).

Economic growth is an indicator to see the success of development and is a necessary condition (necessary conditions) for reducing poverty levels. The condition of sufficiency is that economic growth is effective in reducing poverty. That is, the growth should spread to each income group, including the poor population (Giovanni, 2018).

The GDP value in Java in 2012-2017 has not been able to reduce poverty on the island of Java because the GDP value has experienced fluctuations in each year and has not spread to all groups, both upper, middle, and lower, including the poor population in the province. In addition, the uneven distribution of income has caused community productivity to remain low and has not been able to reduce poverty levels in the provinces of West Java, Central Java, East Java, DIY, Banten and, DKI Jakarta.

According to BAPPENAS, one of the main causes of low productivity is the structural transformation problem, which is about 30 percent of the workforce is in the agricultural sector. The structural transformation problem can be overcome by providing quality 
investment on an ongoing basis, especially in three areas, namely infrastructure, machinery and equipment, and Human Resources (HR). The results of this study are in line with Sussy Susanti's research which states that economic growth (GDP) has a positive and insignificant effect on poverty because GDP is likely not to touch directly in alleviating the poor(Susanti, 2013).

\section{Zakat Moderates Economic Growth (GDP) to Poverty}

From the test results obtained a negative coefficient of 1.579967 with a probability value of 0.1498 greater than $0.05(\alpha)$, in other words, zakat is not able to moderate Economic Growth (GDP) on poverty $\mathrm{H} 4$ is rejected. One of the reasons for the non-functioning of zakat as an instrument of economic equality in the community is that management is not optimal, this is also driven by public knowledge about assets that must be tithed to be limited to conventional sources(Zusiana Elly Triantini, 2015). If in the dialectical cycle there are three important stages namely awareness, knowledge and application, then the position of zakat in Indonesia is still at the level of awareness, and even then not fully and knowledge and towards the application stage. This means that from the dimension of ritual, zakat has a lot to play, but from the socio-economic dimension (productive management has not played a lot, especially in efforts to improve the welfare of the people. This is because they still face problems, including:

a. The zakat fiqh which is developed and understood by Indonesian Muslims is the result of the formulation of the previous scholars so that many are not in accordance with the development of the current era.

b. There is no common perception and steps in the management of zakat so that they do it individually both individuals and groups in accordance with their respective interests.

c. Lack of motivation and outreach to the public about good and correct zakat management.

d. There is no standard management pattern for zakat management to be a joint guideline for zakat fund managers.

At a macro level, economic indicators are not only seen from their growth, but also the level of equity. Economic growth means how much of the goods and services produced in an economic region, while equity means how much of the goods and services produced are enjoyed by residents in the economic area. High economic growth does not necessarily indicate equitable distribution. Likewise, on the contrary, equitable distribution has not shown high growth. In theory, both must be achieved simultaneously, high growth and equitable distribution.

Based on the 2016 Indonesian Gini coefficient in the range of 0.397 in the first semester and 0.394 in the second semester (www.bps.go.id), it means that the level of distribution of income distribution is still in the moderate category. This condition was better in the period 2011-2014 which reached 0.41. The ideal level of inequality should be below 0.3. This condition certainly raises the question, why is the level of income inequality still high?

In the perspective of Islamic economics, the macro balance of income and wealth distribution can be reviewed in three aspects, namely pre-production distribution, post production distribution and redistribution (www.kepribaznas.go.id). First, pre-production distribution, which is the distribution of goods and services before production. To assess whether a country has a policy direction to increase the income of the poor (distributing income to the poor), it can be seen in the structure of the State Budget (APBN). If the APBN structure allocates more budget for the empowerment program for the poor, then the country's policy direction is indeed pro-poverty, in favor of improving the welfare of its people. But on the contrary, if the APBN posture is small for community empowerment programs, then the direction of the policy does not pay attention to the aspect of equity distribution of wealth to the poor. 
Second, post-production distribution, namely the distribution of goods and services after production. Related to goods and services that have been produced with rewards received by each factor of production, such as capital and labor according to their respective contributions, both through market mechanisms and government intervention. The indicator used is the District / City Minimum Wage (UMK) policy for labor groups. Determination of UMK scale based on justice and general benefit will encourage the creation of good development equity.

Third, redistribution is the mechanism of wealth distribution. This mechanism is based on the motive of the existence of threats and rewards offered when working on it. For example, Allah ta, ala threatens to confiscate wealth for those who are mischievous "Never let those who are mischievous with the treasures that Allah gives them from His gift think that ignorance is bad for them. Actually, that mischief will be put on his neck later on the Day of Judgment ... "(QS Ali Imran (3): 180). Allah ta'ala will reward (reward) for those who spend their wealth in the way of Allah ta'ala 700 times as much " ears, in each grain one hundred seeds. ...... "(QS Al Baqarah (2): 261).

Thus, encouraging the development of zakat, infaq, waqf (ZISWAF) is essentially an effort to redistribute assets and wealth, so that economic growth that occurs is truly enjoyed by all levels of society. In addition, the construction of ZISWAF is also an effort to correct problems of injustice that might arise in the pre and post production phases. In general, zakat funds received by Mustahik will increase their purchasing power. This increase will encourage increased production of goods and services. This increase will encourage increased production capacity, which in the end will aggregate drive national economic growth.

However, when these aspects have not been managed optimally such as uneven distribution of income and management of zakat which has not been maximized causing low levels of community productivity, which will result in low levels of community income, this will have an impact on the low ability of the community to saving, which will result in a low level of capital formation. As a result of the low level of capital formation will cause a country will be faced with a shortage of capital goods, thus the level of productivity will remain at a low level so that zakat has not been able to increase economic growth and reduce the level of poverty.

\section{CONCLUSION}

Based on the test data and the conclusions from the discussion the research conclusions can be obtained, as follows:

1. Unemployment has a positive and significant effect on poverty in Java in 2012-2017. This indicates that the more unemployed in Java, the higher the poverty rate. So, there must be a reduction in unemployment like, vocational training centers (BLK), business capital loans and so on.

2. Economic growth (GDP) has a positive and not significant effect on poverty in Java in 2012-2017. In this case, although population growth has increased, it has no effect on poverty levels on the island of Java. That is, one of them is because each region has different GDP standards. So it is not certain that in one region the GDP growth will increase in other regions experiencing the same conditions.

3. Zakat is not able to moderate unemployment to poverty on the island of Java in 20122017. This can be interpreted that the zakat fund has not been able to help reduce unemployment. Because, the zakat funds collected at amil zakat institutions / bodies are not as big as the available potential.

4. Zakat is not able to moderate economic growth (GDP) on poverty in Java in 2012-2017. In this case, the existing zakat fund has not been able to help increase population growth, because the funds collected are not as big as the existing potential. 
In future studies it is recommended to use variable poverty factors that are more diverse as research considerations to get better research results. If the next researcher is interested in conducting a similar study or further research, the researcher should use a greater number of observations so that they produce better conclusions. This study has a limitation that is the data used is still small, using annual data for six years. In addition, the zakat data is only taken from the BAZNAS institution, zakat data from other institutions has not been included.

\section{REFERENCES}

ADESY, D. P. (2016). Ekonomi dan Bisnis. Rajawali Pers.

Alie, M. (2015). Mudah Memahami \& Menganalisis Indikator Ekonomi (Cetakan Ke 2). UPP STIM YKPN Yogyakarta.

Amalia, A. (2017). PENGARUH PENDIDIKAN, PENGANGGURAN DAN KETIMPANGAN GENDER TERHADAP KEMISKINAN DI SUMATERA. AtTawassuth, III(3), 324-344.

Amins, D. B. (2017). PENGARUH TINGKAT PENGANGGURAN TERHADAP TINGKAT KEMISKINAN DI KABUPATEN BERAU Dawami Buchori Amins Sekolah Tinggi Ilmu Ekonomi Muhammadiyah. ECOBUILD : Economy Bring Ultimate Information All About Development Journal Kemakmuran, 1(2), 112-124.

Anak Agung Istri Diah Paramita, I. B. P. P. (2015). PENGARUH INVESTASI DAN PENGANGGURAN TERHADAP PERTUMBUHAN EKONOMI SERTA KEMISKINAN DI PROVINSI BALI. E-Jurnal EP Unud, 4(10), 1194-1218.

Arsyad L. (2015). Ekonomi Pembangunan (Edisi ke-5). UPP STIM YKPN.

Bawono, Anton \& Sina, I. A. F. (2018). Ekonometrika Terapan Untuk Ekonomi dan Bisnis Islam Aplikasi Dengan EVIEWS. LP2M IAIN Salatiga.

Bawono, A. (2006). Multivariabel Analisis dengan SPSS. STAIN Salatiga Press.

BAZNAS. (2018). Indonesiaan Zakat Outlook 2018. Center of Strategic Studies The National Board of Zakat, The Republic of Indonesia (BAZNAS RI).

Beik, Irfan Syauqi \& Arsyanti, L. D. (2016). Ekonomi Pembangunan Syariah. PT Raja Grafindo Persada.

Ghazali, I. (2011). Aplikasi Analisis Multivariate dengan Program IBM SPSS 19. Badan Penerbit Universitas Diponegoro.

Giovanni, R. (2018). Analisis Pengaruh PDRB, Pengangguran dan Pendidikan Terhadap Tingkat Kemiskinan di Pulau Jawa Tahun 2009-2016. Economics Development Analysis Journal, 7(1), 23-31.

Kuncoro, M. (2010). Dasar-Dasar Ekonomi Pembangunan (Edisi 5). UPP STIM YKPN Yogyakarta.

Martono, N. (2011). Metodologi Penelitian Kuantitatif Analisis Isi dan Analisis Data Sekunder. PT Raja Grafindo Persada.

Masruroh, Yulia, Supono, S. (2014). KEMISKINAN DALAM PEMBANGUNAN. Jurnal Analisa Sosiologi, 3(1), 70-90.

Muthohar, A. M. (2016). Potret Pelaksanaan Zakat Di Indonesia Studi Kasus Di Kawasan Jalur Joglosemar. LP2M IAIN Salatiga.

Purnomo, J. H. (2018). Pengaruh Pengelolaan Zakat Terhadap Penanggulanan Kemiskinan Dengan Pemberdayaan Zakat Dan Pendayagunaan Zakat Sebagai Variabel Moderating. TESIS Universitas Islam Negeri Sunan Ampel Surabaya.

Rizal, J., \& Akbar, S. (2015). Perbandingan Uji Stasioner Data Timeseries Antara Metode : Control Chart, Correlogram, Akar Unit Dickey Fuller, dan Derajat Integrasi. Jurnal Gradien, 11(1), 1040-1046.

Romdhoni, A. H., \& Ratnasari, D. (2018). Pengaruh Pengetahuan , Kualitas Pelayanan , Produk, dan Religiusitas terhadap Minat Nasabah untuk Menggunakan Produk 
Simpanan pada Lembaga Keuangan Mikro Syariah. Jurnal Ilmiah Ekonomi Islam, 4(02), 136-147.

Romi, S., \& Umiyati, E. (2018). Pengaruh pertumbuhan ekonomi dan upah minimum terhadap kemiskinan di Kota Jambi. E-Jurnal Perspektif Ekonomi Dan Pembangunan Daerah, 7(1), 1-7.

Soetomo. (2008). Masalah Sosial Dan Upaya Pemecahanya. Pustaka Pelajar.

Sujarweni, W. (2015). Metodologi Penelitian Bisnis dan Ekonomi. PT Pustaka Baru.

Sukirno, S. (2006). Makro Ekonomi Teori Pengantar (Edisi ke t). PT Raja Grafindo Persada.

Sularno, M. (2010). Pengelolaan Zakat oleh Badan Amil Zakat Daerah Kabupaten / Kota Se Daerah Istimewa Yogyakarta. Jurnal. La_Riba Jurnal Ekonomi Islam, IV(1).

Sullutenggomalut, D., \& Sadjab, M. R. (2016). PENGARUH KOMPENSASI (FINANSIAL DAN NON FINANSIAL) TERHADAP PRESTASI KERJA KARYAWAN DJKN SULLUTENGGOMALUT. Jurnal EMBA, 4(3), 760-770.

Susanti, S. (2013). Pengaruh Produk Domestik Regional Bruto , Pengangguran dan Indeks Pembangunan Manusia terhadap Kemiskinan di Jawa Barat dengan Menggunakan Analisis Data Panel. Jurnal Matematika Integratif, 9(1), 1-18.

Zusiana Elly Triantini. (2015). Urgensi Regulasi Zakat Dalam Pertumbuhan Ekonomi Di Indonesia. Istinbath, Jurnal Hukum Islam, 14(1), 85-99. 